\title{
Determinants of Food Industry Competitiveness in China from the Perspectives of Porter's Diamond Model
}

\author{
Longhua Zhao \\ College of Economics and Management \\ Tianjin University of Science and Technology \\ Tianjin, China
}

\begin{abstract}
Indices and measurements of food industry competitiveness with an international approach are required to potentially measure food industry productivity and raise national competitiveness worldwide. This study developed assessment criteria of food industry competitiveness based on Porter's diamond model, reset food industry competitiveness indices, and finally add innovation as a key factor affecting all other indices. The results indicate that there are seven indicators: production factors, demand conditions, supportive industries, enterprise strategy, industry structure and competitive environment, government policies and innovation. These research results intend to provide food industry policy makers with some strategic recommendations, and may serve as a baseline for further food industry studies using Porter's diamond model.
\end{abstract}

Keywords-food industry competitiveness; porter's diamond model; international competitiveness; assessment indices

\section{INTRODUCTION}

With the change and evolution of world economic structure and emergence of international competitiveness, food industry is an important embodiment of the acceleration of the process of economic integration in the world. International competitiveness of industry is derived from the concept of international competitiveness. From the input and output theory, comparison and assessment of international competitiveness help figure out the indices of international competitiveness by analyzing the law of industry development. Those indices provide suggestions for promoting international competitiveness. Based on international competitiveness in industry, international competitiveness of food industry is analyzed to construct systematical research framework for food industry in China. This research results intend to provide food industry policy makers with some strategic recommendations, and may serve as a baseline for further food industry studies using Porter's diamond model.

\section{LITERATURE REVIEW}

\section{A. Porter's Diamond's Model}

The current research on industrial competitiveness evaluation index is relatively mature, mainly Michael Potter's "Diamond Model" in the United States Harvard University strategic management and the Swiss Lausanne International Management Institute (IMD) and the World Economic Forum (WEF) competitiveness theory and evaluation system. Porter by using the "Diamond Model" theoretical framework on the competitiveness of interpretation and evaluation, think industry competitiveness is a country presented competition ability in the international market. He believes that the country's competitive advantage lies in four key elements: (1) factor conditions(FC):Investment in a particular industry, including labor, natural resources, technical knowledge, funds, infrastructure, and so on. (2) Demand condition (DC): The scale, speed and characteristics of the demand for products or services provided by the domestic market, and the prediction of domestic demand for foreign market demand. (3) Related and supporting food industry industries (RSLI): Whether there are internationally competitive upstream industrial suppliers and related industries that can coordinate or participate in value chain activities in China. (4) The situation of enterprise strategy, structure and competition. The company's operation and management as well as the way to choose the competitive industry, the company's goals, the degree of competition in the country, and the ability to establish and maintain the competitive advantage of specific industries. Potter made a systematic analysis of the four elements, in addition, Potter also pointed out that in addition to these four factors, the relationship between national environment and the competitiveness of enterprises, "opportunity" and "government" is the two important factors, these six factors constitute the competitive advantage of nations "complete diamond system" (also known as "the Potter model,") this model has important effect on the development of competence theory.[1]

Dunning put forward the international diamond model, and introduced the influence of "multinational company's 
business activities" on the competitiveness of a country. Later it was called the "Potter Denning" model.[2] Cartwright the "multi factor model" was proposed in New Zealand as an example, and the diamond model was amended to explain the international competitiveness of small countries.[3] Rugman and Cruz built a double diamond model to study the competitiveness difference between big trading countries and small ones when studying Canadian competitive advantage. [4]Moon et al. further overcome the limitation of trade scale of double diamond models, and put forward a generalized double diamond model with stronger understanding and wider application.[5] It can be seen that the diamond model has been perfected and developed, and has been universally applicable to a considerable extent.

At present, scholars based on Potter and Denning and the situation of industrial development in various countries, produces some new evaluation indicators for industrial competitiveness, but Potter's contribution to this academic has laid the foundation for the research of national competitiveness.

\section{B. Domestic Studies on Conditions}

Based on the input and output theory of industry, Sun Jiguang compares and evaluates the international competitiveness of an industry in a certain country, and analyzes the law of industrial development to find out the main factors that affect the international competitiveness of the industry.[6] Song Dejun and others pointed out that green food industry international competition ability is based on the integration of the comparative advantages of regional factors. According to green food production in Heilongjiang province, demand conditions, natural resources, industry, and so on and so forth are required to build international competitiveness evaluation index system of green food industry.[7] Taking "Chinese food city - Luohe city in Henan province as an example, Zhang Yuanbin based on the statistical data collected between 2006-2012, analyzed city food industrial structure and competitiveness through the empirical analysis by integrating structural analysis, deviation-share analysis, location quotient, market-share analysis and other methods.[8] Zhang Meihui used international trade and international competitiveness theory as the foundation and theoretical analysis framework, to build up international competitiveness index to calculate and determine the Thai agricultural competitiveness.[9] $\mathrm{Hu}$ Bentian used the ten industry panel data of 2000-2014 to assess the international competitiveness of Chinese industry, on the basis of empirical research on the standardization level of effect of industrial international competitiveness. It is found that the international competitiveness of our industry is sensitive to the standardization level.[10]

Domestic scholars have different understanding of international competitiveness and different research preference, and different assessment systems are selected in the competitiveness evaluation. For the food industry international competitiveness analysis, there are some scholars set up the index system to evaluate, but evaluation index are not comprehensive. Along with the transformation and upgrading of China's manufacturing industry, however, the studies on the international competitiveness of manufacturing, Feng Zhen and Zhao Yanyun make a comparison of the international competitiveness of Chinese manufacturing of 2007 by using production efficiency, labor costs, product market, employee motivation, enterprise system, independent innovation, innovation network as seven indicators of manufacturing international competitiveness evaluation.[11] Li Lianshui extended the three dimensional evaluation system further into the economic creativity, science and technology innovation ability five aspects, such as perfecting the manufacturing, to evaluate multidimensional "new-type" manufacturing.[12] With the help of index evaluation system of manufacturing industry, innovation, innovation network, resources and environment protection, science and technology innovation ability and so on, some of the new evaluation index to join international competitiveness evaluation system, which is in accordance with the present stage of development idea and development requirements in the new era. Sun Ting and others combing the current manufacturing industry development on the basis of the obstacle and opportunity, mainly concentrated in the establishment of the industry's competitiveness evaluation index system, extract the four key factors that affect manufacturing industry international competitiveness, namely elements (Factor), environmental Regulation (Regulation), the system (Institution), Technology innovation (Technology), FRIT evaluation framework.[13] To sum up, combining with the existing scholar's research results, the food industry international competitiveness research will be based on the factor conditions, demand conditions, related and supporting industries, enterprise competitive strategy, structure and elements, and to subdivide the four elements, combined with the achievement transformation, environmental capacity, technological innovation, system innovation and other elements.

To sum up, the international competitiveness of research based on porter's theory of international competition, combining with the characteristics of their own or the industry, by analyzing the development of this industry. Through the literature review, the focus on the systematic evaluation of international competitiveness is mainly concentrated in the establishment of evaluation index system. It is not hard to find, the main index system lies in potter's four elements: factor conditions, demand conditions, related and supporting industries, enterprise strategy, structure and competition condition is a systemic analysis.[14] In addition, there are also some for the "government", especially the elements of the "innovation" to consider for developing countries. (1) factor conditions(FC): at present, China's food industry development in the growth stage, the food industry competition the necessary inputs, including labor, natural resources, technology, capital, infrastructure, etc. At present, China's labor dividend is declining, which is very bad for the development of the industry. Besides, the technical knowledge is still in the growth stage compared with the developed countries. (2) demand condition (DC): the factors influencing the food industry international competitiveness, is the size of the domestic and international market demand, in accordance with the current China's stage of economic 
development and people's actual consumption level, consumption is in rapid expansion, potential consumer market, especially with the improvement of living standards, the pursuit of quality, so the development of food industry with a high level of market demand, market demand for the development of the industry will play a vital role. (3) Related and supporting food industry industries (RSLI): if a country or region there food industry internationally competitive suppliers, perfecting the related with the support of the industrial chain, such as product logistics, industrial park, etc., can reduce production cost, improve product quality, so as to establish their own competitive advantage. Therefore, the development level of relevant and supportive industries and their frequent and close coordination and cooperation have greatly affected the development level of international competitiveness of the food industry. (4) enterprise strategy: leading food enterprises have monopolistic market competition ability. It is established on the basis of the food industry leading enterprises in the core resources of enterprise technology, product, brand, management, culture and so on the reflection of comprehensive advantage in the market, make the enterprise in the process of management is to guide the healthy development of industry, has the unique ability to competitive advantage. (5) International firm strategy structure and rivalry (IFSSR): refers to the industry internal resource allocation structure and the mutual connection, mainly including industrial concentration, dispersion, industry market structure region agglomeration effects, etc., the food industry with the improvement of factor conditions, market competition intensifies, door entry increase, industry to the influence of institutional change and the change of income, food industry organization structure has been optimized, and the lack of food industry in China is the competitive advantage of industrial organization structure optimization. Food industry in China has gone through the industrial development cycle of import stage, growth stage, mature stage and decline stage, and into the growth period, therefore, the enterprise's marketing ability, market demand, will become the main factor of competitiveness of international industry. (6) The government behavior: this includes local government policies as well as central government policy; as the market main body, the development of the market mechanism is not mature, the government's industrial policy will affect the food industry international competitiveness, or become a decisive factor in the development of internationalization. (7) Innovation: after growth of moderate scale development of food industry in China must actively promote the food industry to make the transition to maturity, the focus of the government industrial policy is not to do "big" but "strong", through adjustment of industrial structure, improve the technical content and innovation of the food industry, industrial competitiveness is growing. Those seven factors are highly connected with each other as shown in "Fig. 1".

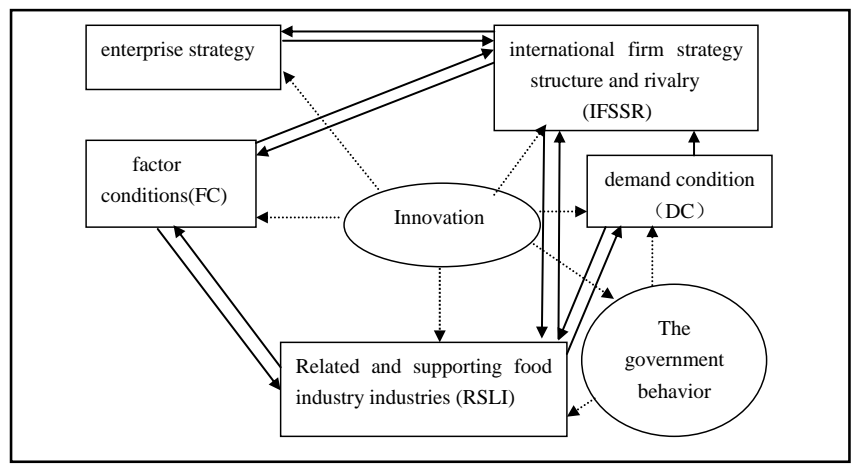

Fig. 1. Framework of the systematic evaluation of International C.

\section{Food Industry}

Given the objectivity of factor evaluation, the selection of indicators mainly covers the potential of industrial development, the input and output of industry and environmental support. At the same time, considering the information completeness, relevance and the scalability of data, the food industry international competitiveness evaluation index system mainly by the industrial factor, demand factor, the enterprise operation and competition elements and related support as evaluation index of level, these elements from different sides reflects the result of the ascension of the food industry international competitiveness dynamics, through the analysis of the factor index to judge, can be traced dynamically improve problem of deficiency, facilitate problem analysis and countermeasures. The international competitiveness evaluation system can be designed according to the evaluation elements of international competitiveness of food industry (see table below). Through the statistics of the evaluation results of these indicators, the overall situation of food industry's international competitiveness can be comprehensively evaluated and judged. Evaluation index system of international competitiveness of food industry: 
TABLE I. EVALUATION INDEX SySTEM OF INTERNATIONAL COMPETITIVENESS OF FOOD INDUSTRY

\begin{tabular}{|c|c|c|c|}
\hline $\begin{array}{l}\text { Objective } \\
\text { layer } 1(\mathrm{~A})\end{array}$ & $\begin{array}{l}\text { criteria layer } 2 \\
\text { (B) }\end{array}$ & sub-criteria layer 3 (C) & indicators category \\
\hline & \multirow{4}{*}{$\begin{array}{c}\text { factor } \\
\text { conditions(FC) } \\
(\mathrm{X} 1)\end{array}$} & \multirow{4}{*}{$\begin{array}{l}\text { product yield (X11) } \\
\text { Labor skill level (X12) } \\
\text { National leader product number (X13) } \\
\text { Natural resources (X14) } \\
\end{array}$} & quantitative data \\
\hline & & & quantitative data \\
\hline & & & quantitative data \\
\hline & & & quantitative data \\
\hline & \multirow{4}{*}{$\begin{array}{c}\text { demand } \\
\text { condition } \\
(\mathrm{DC}) \quad(\mathrm{X} 2)\end{array}$} & \multirow{4}{*}{$\begin{array}{l}\text { market demand scale }(\mathrm{X} 21) \\
\text { Food safety }(\mathrm{X} 22) \\
\text { Education degree }(\mathrm{X} 23) \\
\text { Consumption level (X24) }\end{array}$} & quantitative data \\
\hline & & & qualitative data \\
\hline & & & qualitative data \\
\hline & & & quantitative data \\
\hline & \multirow{4}{*}{$\begin{array}{l}\text { Related and } \\
\text { supporting food } \\
\text { industry } \\
\text { industries } \\
\text { (RSLI) (X3) }\end{array}$} & \multirow{4}{*}{$\begin{array}{l}\text { area of environmental monitoring } \\
\text { (X31) } \\
\text { Work organization and team } \\
\text { construction (X32) } \\
\text { Quantity of product development } \\
\text { products (X33) } \\
\text { Product logistics (X34) } \\
\end{array}$} & quantitative data \\
\hline & & & quantitative data \\
\hline & & & quantitative data \\
\hline & & & quantitative data \\
\hline & \multirow{4}{*}{$\begin{array}{c}\text { enterprise } \\
\text { strategy (X4) }\end{array}$} & \multirow{4}{*}{$\begin{array}{l}\text { leading food enterprises (X41) } \\
\text { Number of professional cooperatives } \\
\text { (X42) } \\
\text { Production technology (X43) } \\
\text { The construction scale of raw material } \\
\text { standardization production base (X44) }\end{array}$} & quantitative data \\
\hline & & & quantitative data \\
\hline & & & qualitative data \\
\hline & & & quantitative data \\
\hline & \multirow{4}{*}{$\begin{array}{l}\text { international } \\
\text { firm strategy } \\
\text { structure and } \\
\text { rivalry (IFSSR) } \\
\quad \text { (X5) }\end{array}$} & \multirow{4}{*}{$\begin{array}{l}\text { exports account for the share of } \\
\text { China's exports (X51) } \\
\text { Enterprise scale (X52) } \\
\text { Brand operation (X53) } \\
\text { The construction of industrial district } \\
\text { (X54) }\end{array}$} & quantitative data \\
\hline & & & quantitative data \\
\hline & & & qualitative data \\
\hline & & & quantitative data \\
\hline & \multirow{4}{*}{$\begin{array}{c}\text { The government } \\
\text { behavior } \\
\text { (X6) }\end{array}$} & \multirow{4}{*}{$\begin{array}{l}\text { market mechanism development } \\
\text { (X61) } \\
\text { Government industrial policy (X62) } \\
\text { National development strategy } \\
\text { (opportunity) (X63) } \\
\text { Government part management } \\
\text { (X64)) }\end{array}$} & qualitative data \\
\hline & & & qualitative data \\
\hline & & & qualitative data \\
\hline & & & qualitative data \\
\hline & \multirow{4}{*}{$\begin{array}{l}\text { Innovation } \\
\text { (X7) }\end{array}$} & \multirow{4}{*}{$\begin{array}{l}\text { product technology content (X71) } \\
\text { Industrial structure (X72) } \\
\text { Industrial development stage (X73) } \\
\text { Innovative ability (X74) }\end{array}$} & qualitative data \\
\hline & & & quantitative data \\
\hline & & & qualitative data \\
\hline & & & momlitative data \\
\hline
\end{tabular}

As "Table I" shows, the primary criterion layer two is the basic factor layer, also known as the primary index; The sub-criterion layer 3 is the concrete factor layer, also known as the secondary index. Their relationship is $\mathrm{X}=(\mathrm{X} 1, \mathrm{X} 2, \mathrm{X} 3, \mathrm{X} 4, \mathrm{X} 5, \mathrm{X} 6, \mathrm{X} 7), \mathrm{X} 2=(\mathrm{x} 11, \mathrm{x} 12, \mathrm{x} 13, \mathrm{x} 14)$, $\mathrm{X} 2=(\mathrm{x} 21, \mathrm{x} 22, \mathrm{x} 23, \mathrm{x} 24), \mathrm{X} 3=(\mathrm{x} 31, \mathrm{x} 32, \mathrm{x} 33, \mathrm{x} 34), \mathrm{X} 4=(\mathrm{x} 41$, $x 43, x 43, x 43, x 43, x 43, x 43, x 43, x 43, x 43, x 43)$, $X 5=(x 51, x 52, x 53, \quad x 53, \quad x 54), \quad X 6=(x 61, x 62, x 63, \quad x 64)$, $\mathrm{X6}=(\mathrm{x} 61, \mathrm{x} 62, \mathrm{x} 63, \quad \mathrm{x} 64), \quad \mathrm{X} 7=(\mathrm{x} 71, \quad \mathrm{x} 62, \mathrm{x} 63, \quad \mathrm{x} 64)$, $X 7=(x 71, x 72, x 72, x 73, x 73, x 73, x 73, x 74)$. Due to the reflection of the food industry international competitiveness indicators, considering a different unit, to eliminate the influence of the unit, should be dealt with dimensionless evaluation index, the need to evaluation of each index respectively, the comparison of the respective standard, and according to the weight of each index, through quantitative (that is, to determine the membership degree) into measurable evaluation scores, and individual scores of each index together, get comprehensive evaluation score.

\section{METHODOLOGY}

Fuzzy comprehensive evaluation method is a comprehensive evaluation method based on fuzzy mathematics. The membership degree of fuzzy mathematics comprehensive evaluation method based on the theory of the qualitative evaluation into quantitative evaluation, which USES fuzzy mathematics to is restricted by various factors of things or object to make an overall evaluation. We quantified the indicators of international competitiveness of the food industry (i.e. the degree of membership), and then used the fuzzy comprehensive evaluation method to synthesize the indicators. 
- Determine that factors domain includes $\mathrm{P}$ evaluation indicators, $\mu=\{\mu 1, \mu 2, \ldots \ldots, \mu \mathrm{p}\}$.

- Determine the rating scale of evaluation domain $\mathrm{V}=\{v 1, v 2, \ldots \ldots, v p\}$, which is a hierarchical set. Each level can correspond to a fuzzy subset.

- To establish a fuzzy relational matrix, after constructing a hierarchical fuzzy subset, each of the factors should be evaluated individual $\mu$ $\mathrm{i}(\mathrm{i}=1,2, \ldots \ldots, \mathrm{p})$. Namely to determine from the single factor were things to rank the membership degree of fuzzy subset $(\mathrm{R} \mid \mu \mathrm{i})$, the fuzzy relationship matrix is obtained: determine the evaluation object factor (indicators) of collection evaluation (grade) set; The weight of each factor and its membership vector are determined respectively, and the fuzzy evaluation matrix is obtained. Finally, the fuzzy evaluation matrix and the weight vector of the factors are fuzzy and normalized, and the fuzzy comprehensive evaluation results are obtained.

Through the analysis of the factors of indicators, it can be found indices in the food industry in the international competition facilitate problem analysis and countermeasuresmaking, food industry internationalization development strategy for the government to provide theoretical basis.

\section{CONCLUSION}

From the review of the above illustration, it can be seen that the research on international competitiveness begins with the strategic management master Michael porter, which analyzes the factors, requirements, relevant and supporting industries, corporate strategy, structure and competitive situation. Besides, porter also points out that in addition to these four elements, "opportunity" and "government" are two indispensable elements in the relationship between national environment and enterprise competitiveness. These six factors constitute the complete national competitive advantage "diamond system" (also known as "the potter model"). Many scholars have developed the theoretical basis for the study. Domestic scholars on national competitiveness or industry competitiveness research mainly towards the study of manufacturing industry, it also benefited from the urgency of the reform of China's manufacturing industry, at present, China's manufacturing industry is still in the international division of labor in the mid-range, such problems as big and outstanding, promote manufacturing quality upgrade urgent task, it is also important to push forward the reform of supply side structural content. Also strong response of the CPC central committee to speed up the construction of manufacturing strategy, to carry out the new development idea, implement the strategy of innovation driven development, with "made in China 2025" for the gripper driven manufacturing quality upgrading, resolutely eliminate backward production capacity and technology, speed up the old and the new kinetic energy transformation, promote China's economy towards the high end goals. The competitiveness of manufacturing industry is a complex system, so the research should be carried out at multiple levels in order to make the conclusion fair and objective and comprehensive and accurate. However, it is regrettable that so far, scholars' research mainly focused on systematic evaluation of the international competitiveness of manufacturing industry, and analyzed the key factors that influence competitiveness. In addition, some scholars have studied the international competitiveness of these industries in terms of agriculture, cultural industry and the impact of standardization on the international competitiveness of industries. Finally, this paper takes "the food industry's international competitiveness" as the focus, focus on the international competitiveness of the food industry, found some scholars from the theory analysis of the food industry comparative advantage and strong competitiveness; There are different from the natural conditions and natural resources, labor quality, science and technology development level, and four aspects analyzes the industrial concentration degree, analysis of the food products in the western developed countries with strong international competitiveness, food processing industry has an important impact on the world, system research has an important theoretical basis for the food processing industry international competitiveness; There are also four main factors that affect the international competitiveness of Thai agriculture: productivity, market share, export prices and exchange rates. In this paper, innovation has proposed to be a factor as the competitiveness of a country, and revised the diamond model to illustrate the international competitiveness of countries. This provides a theoretical basis for the study of industry competitiveness in new century, and provides direction for the research of individual industry and the determination of index system.

To sum up, the international competitiveness of research based on porter's theory of international competition, to understand the characteristics of their own or the industry, analysis the development of this industry, the focus is on the systematic evaluation of international competitiveness are mainly concentrated in the establishment of evaluation index system, combining with literature, it is not hard to find, the main index system lies in potter's four elements: Factor conditions, demand conditions, related and supporting industries, enterprise strategy, structure and competition condition is a systemic analysis of the four elements, in addition, there are also some for the elements of the "government", the domestic scholars for the industrial international competitiveness evaluation index system on productivity, market share, export prices and exchange rates, natural conditions and natural resources, labor quality, science and technology development level and the degree of centralization, industrial production elements (Factor), environmental Regulation (Regulation), the system (Institution) (Technology), technological innovation, economic creation ability, innovation ability of science and Technology, production elements, demand factors, industry associations, enterprises, government behavior and trade behavior level, production efficiency, labor costs, product market, employee motivation, enterprise system, independent innovation, innovation network, support, investment, transformation, output and environmental capacity, technology innovation, system innovation, market innovation, economic, science and technology competition 
and resource environmental protection index to evaluate the international competitiveness. Nearly two years of study, many scholars to the innovation, the innovation network, resources and environment protection, science and technology innovation ability and so on some of the new evaluation index to join international competitiveness evaluation system, which is in accordance with the present stage of development idea and development requirements. Combining with the existing scholar's research results, the food industry international competitiveness research will be based on the factor conditions, demand conditions, related and supporting industries, enterprise competitive strategy, structure and the four elements, and subdivide the four elements, combined with the achievement transformation, output and environmental capacity, technological innovation, system innovation and other elements.

\section{REFERENCES}

[1] Porter. M.E. Porter. The Competitive Advantage of Nations. Free Press, New York, 1990.

[2] Dunning J. H., Norman G., The Location Choice of Offices of International Companies. Environment and Planning, 1987, pp. 613631.

[3] Cartwright W R., 1993. Multiple Linked "Diamonds" and the International Competitiveness of Export---dependent. Industries: The New Zealand Experience. MIR: Management International Review 1993, pp. 55- 70.

[4] Rugman A. M., Cruz J. R., The "Double Diamond" Model of International Competitiveness: The Canadian experience. MIR: Management International Re-view, 1993, pp. 17-39

[5] Moon H C, Rugman A. M., Verbeke A., 1998. A Generalized Double Diamond Approach to the Global Competitiveness of Korea and Singapore, International Business Review, 1998, pp. 135-150.

[6] Sun Jiguang, The Contemporary Capitalism and Northeast Regional Economics[D], Northeast Research Institution, 2013.

[7] Song Dejun, Zhou Tong, et al, 2013The Choice of Hei Longiiang Green Food Industry International Competitiveness Evaluation Index and Model Building Research Based on the Green Food Industry International. Competitiveness Factors[J], Journal of Commercial Economy, Vol. 8 pp.7-9, 2013.

[8] Zhang Yuanbin, et al, 2014.Empirical Analysis of the Structure and Competitiveness of Food Industry in Luohe city, Henan Province Resource Development and Market, 1362 (2014), pp. 1362-1365

[9] Zhang Meihui, Empirical Analysis on Factors Affecting the Agricultural International Competitiveness, Institute of International Economic and Trade, University of Foreign Economics and Trade,Vol. 7 2016), pp. 6-166

[10] Hu Bentian, Chen leying, Research on the Relationship Between Standardization and Industrial International Competitiveness, China university of north China science and technology (social science edition), Vol. 44, pp. 44-50, 2017.

[11] Zhen Feng, Zhao Yanyun, International Competitiveness of China's Manufacturing Industry: International Comparative Study in 2007, China Soft Science, 2008, pp. 47-54.

[12] Li lian shui, Zhou yong, Empirical Analysis of the "New-type" Situation of Chinese Manufacturing Industry: Based on the Study of Manufacturing evaluation in 30 regions of China, Management world, 2005, pp. 76-81

[13] Sun Ting, Yu Donghua, Li Jie, 2017. Evaluation of Manufacturing International Competitiveness Based on the FRIT Framework -- and the Nonlinear Effect of Environmental Regulation, Economic problem Exploration, 2017, pp. 153-162.

[14] Porter M. E., The Competitive Advantage of Notions, Harvard Business Review, 1990, pp. 73-93. 